\title{
Diagnosis of mycobacterial drug resistance in HIV reactive patients by phenotypic and genotypic assay - a comparative study
}

\author{
S Umamaheshwari', Sumana M Neelambike ${ }^{1 *}$, K Anuradha $^{2}$, B Sumangala ${ }^{3}$ \\ From 2nd International Science Symposium on HIV and Infectious Diseases (HIV SCIENCE 2014) \\ Chennai, India. 30 January - 1 February 2014
}

\section{Background}

Emergence of drug resistance has complicated the treatment of Tuberculosis (TB). WHO reports India as one among 27 "high burden" multidrug resistant (MDR) TB countries. The study was carried out to detect drug resistance of mycobacterial isolates in HIV patients.

\section{Methods}

The clinical specimens collected from HIV seropositive AFB smear negative patients (Group A) with features of $\mathrm{TB}, \mathrm{AFB}$ smear positive, HIV reactive (Group B) and AFB smear positive, HIV negative (Group C) were processed as per standard protocol. They were inoculated onto Lowenstein Jensen media and the isolates obtained were subjected to drug susceptibility test (DST) by proportion method and Genotype MTBDR plus assay.

\section{Results}

In Group A out of 162 patients, 443 clinical samples were collected and 76 mycobacterial strains were obtained from 67 (41\%) patients. In this 69 (91\%) were Mycobacterium tuberculosis complex and 7 (9\%) were Mycobacterium avium complex. As per phenotypic method, of 76 isolates, $50(65.8 \%)$ were sensitive to all drugs and $26(34.2 \%)$ resistant to one or more drugs. The MDR and resistance to at least single drug of Group A, B and C were [5 (6.6\%), $2(6.7 \%), 4(8 \%)]$ and $[26(34.2 \%, 3(10 \%), 8(16 \%)]$ respectively. MTBDR assay showed similar results except one discrepancy i.e., one isolate was resistant to rifampicin that was sensitive in proportion method.

\footnotetext{
* Correspondence: mnsumana12@gmail.com

'Department of Microbiology, JSS Medical College, Mysore, Karnataka, India Full list of author information is available at the end of the article
}

\section{Conclusion}

The increase of MDRTB in high TB burden settings stresses the need for DST. This helps in providing proper treatment regimens, improve prognosis and prevent the spread of drug resistant TB.

\section{Authors' details}

${ }^{1}$ Department of Microbiology, JSS Medical College, Mysore, Karnataka, India. ${ }^{2}$ Department of Microbiology, Mysore Medical College and Research Centre, Mysore, Karnataka India. ${ }^{3}$ Department of Microbiology, Mandya Institute of Medical Sciences, Mandya, Karnataka, India.

Published: 27 May 2014

\section{doi:10.1186/1471-2334-14-S3-P58}

Cite this article as: Umamaheshwari et al: Diagnosis of mycobacterial drug resistance in HIV reactive patients by phenotypic and genotypic assay - a comparative study. BMC Infectious Diseases 2014 14(Suppl 3):P58.
Submit your next manuscript to BioMed Central and take full advantage of:

- Convenient online submission

- Thorough peer review

- No space constraints or color figure charges

- Immediate publication on acceptance

- Inclusion in PubMed, CAS, Scopus and Google Scholar

- Research which is freely available for redistribution
() Biomed Central 